\title{
ESTRATÉGIAS DE MEDIAÇÃO SIMBÓLICA EM UM CALUNDU COLONIAL
}

\author{
Alexandre Almeida Marcussi \\ Mestrando em História Social - FFLCH/USP
}

\section{Resumo}

Este artigo procura interpretar o processo inquisitorial de Luzia Pinta, praticante de ritos mágico-religiosos denominados calundus em Sabará no século XVIII, com o objetivo de analisar as estratégias e os percursos de mediação simbólica entre tradições religiosas africanas e o catolicismo que engendraram a elaboração de novas práticas simbólicas na América Portuguesa.

\section{Pallavras-Chave}

Religiosidade afro-americana • Práticas Mágicas • Mediação Cultural

\section{Abstract}

This article is an interpretation of the inquisitorial process against Luzia Pinta, practiser of magical-religious rites called calundus in Sabará in the XVIIIth century, intending to analyze the strategies and routes of symbolical mediation between African religious traditions and the Catholicism, which engendered the elaboration of new symbolical practices in Portuguese America.

\section{Keywords}

African-American religiosity $\bullet$ Magical Practices $\bullet$ Cultural Mediation

\footnotetext{
"A pesquisa de Iniciação Científica que deu origem a este artigo foi financiada pelo PIBIC/ CNPq e pela FAPESP.
} 


\section{Introdução: Ambigüidades do olhar}

Os olhares lançados por europeus, colonos e brancos sobre seus escravos africanos na América Portuguesa tecem uma história de ambigüidades. Na claridade idealizada pelos discursos escravistas, os escravos eram o próprio espaço exemplar de uma obra da salvação, na medida em que, libertos das trevas a que estariam condenados em suas terras natais, teriam sido levados à América cristã para serem salvos pelo conhecimento da verdadeira fé e pela misericórdia de Cristo. O trabalho e as imposições a que se submetiam eram tanto um aprendizado árduo das regras de civilidade que se punham como condição para o exercício de uma fé racional e verdadeira, quanto uma penitência a pagar pelos pecados abomináveis de sua existência pregressa. Nos castigos corporais, o que se inscrevia na própria carne dos africanos era o signo de sua salvação. Sob esse olhar domesticador, eles eram a imagem cristalina da obra de construção de uma sociedade alicerçada nos preceitos da religião, uma Cidade de Deus que se oferecia como possibilidade universal de salvação a todos os povos em contato com o Império Português. ${ }^{1}$

Por outro lado, eram também objetos de um olhar de repúdio e aversão, na medida em que raramente se adequavam com perfeição a esse modelo ideal. Seus costumes e práticas religiosas trazidos da África, abomináveis aos olhos europeus, eram vistos e temidos como demoníacos. Através de seus batuques, festejos, danças e revoltas, quem falava e agia era o próprio Demônio com sua influência nefasta e destruidora, corrompendo a moralidade da colônia e transformando-a em um lugar da perdição das almas. Se, por um lado, eram o suporte e lugar de uma obra de salvação, por outro lado eram um risco que poderia levar à sua dissolução.

O olhar senhorial sobre seus escravos não era menos ambíguo. Por um lado, eles eram a mão-de-obra sobre a qual se assentava a riqueza do senhor e seu investimento maior; por outro lado, eram a encarnação sempre presente de um temor profundo, na medida em que eram rebeldes em potencial, prontos para destruir a ordem colonial e ameaçar a riqueza e a vida de seus senhores.

\footnotetext{
${ }^{1}$ Para os fundamentos desse discurso colonial católico apoiado na cristianização, ver PAGDEN, Anthony. "Monarchia universalis". In: Señores de todo el mundo: Ideologías del imperio e España, Inglaterra y Francia (en los siglos XVI, XVII y XVIII). Barcelona: Península, 1997, p. 45-86.
} 
Nos escravos estava a afirmação da ordem colonial e também a possibilidade de sua negação.

A ambigüidade do olhar europeu, lançado através dessa dupla lente, cristã e econômica, movia-se entre a identificação narcísica, que via no africano uma imagem especular do europeu enquanto pecador em busca da salvação, e o horror e aversão que o viam como sua negação. Essa ambigüidade delineou um inventário de papéis simbólicos a serem encarnados pelos senhores, eclesiásticos e escravos, e prefigurou lugares onde se davam as relações sociais e simbólicas na colônia. Sob este olhar ambivalente, o escravo se transformava ora em trabalhador obediente e leal, ora em objeto de punição, castigo e repressão.

Laura de Mello e Souza atentou para essa ambivalência dos olhares cristãos sobre a realidade colonial, oscilando entre a edenização e a demonização. ${ }^{2}$ Ainda que a aversão prevalecesse na representação do universo social e dos africanos, projetando imagens advindas de um imaginário do horror que se configurava a partir da linguagem demonológica, a identificação cristã seguia sendo seu avesso, às vezes subterrâneo mas sempre necessário como contraponto ou ideal do qual a imagem demonizada se desviava, e em relação ao qual se configurava como objeto de aversão. A ambigüidade era assim o idioma da apreensão e de construção do outro que o constituía ao mesmo tempo como suporte e como negação de uma ordem social, e criava espaços nos quais ele era fixado e representado através de um espectro abrangente de modalidades legítimas de relação social pelas quais a realidade colonial se construía: as relações de trabalho, a punição, a repressão. ${ }^{3}$

Esse olhar constituiu espaços discursivos nos quais as práticas desviantes podiam ser apreendidas de formas enviesadas e marcadas pela aversão e pela incompreensão. Sua alteridade, risco permanente de dissolução das representações da universalidade católica, é representada de forma reduzida através da projeção do imaginário do horror e do demoníaco, o que atenua a tensão e regenera o discurso ameaçado por uma alteridade que se constitui no embate

${ }^{2}$ Cf. SOUZA, Laura de Mello. Inferno Atlântico: Demonologia e colonização: Séculos XVIXVIII. São Paulo: Companhia das Letras, 1993; e SOUZA, Laura de Mello. O diabo e a terra de Santa Cruz: Feitiçaria e religiosidade popular no Brasil colonial. São Paulo: Companhia das Letras, 1987.

${ }^{3}$ Cf. BHABHA, Homi. O local da cultura. Belo Horizonte: Ed. UFMG, 1998, p. 105-128. 
com a ordem. Os espaços simbólicos e institucionais onde se produz essa redução da alteridade são, por isso, alçados à condição de espetáculos onde a ordem se reconstrói e se impermeabiliza contra a dissolução.

Num universo simbólico e discursivo marcado pela justificação religiosa da escravidão, as práticas mágicas dos africanos são um dos pontos nodais dessa alteridade desestruturante dos discursos oficiais. Trazidos à América para que abandonassem a idolatria de sua terra natal e abraçassem a possibilidade da salvação, eles punham em xeque esse discurso quando continuavam recorrendo a práticas mágicas abomináveis e demoníacas e construíam a alteridade nesse embate. A Inquisição, por sua vez, era um desses espaços institucionais espetacularizados onde a ordem se recompunha através da redução dessa alteridade. Longe do olhar dos senhores, conspirando, preparando revoltas, vivendo uma religiosidade diferente daquela dos eclesiásticos ou simplesmente se divertindo, os africanos e seus descendentes só podiam ser apreendidos através de um olhar necessariamente enviesado por essas estratégias discursivas. Recompor as práticas e espaços de marginalidade onde eles reelaboravam e subvertiam a ordem escravista, apreender as lógicas de construção simbólica e pragmática a que recorriam na constituição dessas práticas e compreender as estratégias pelas quais o discurso dominante representava essas alteridades para a elaboração de práticas normatizadoras apresenta-se como tarefa necessária para a compreensão da construção de uma sociedade colonial.

Este estudo tenta lançar luz sobre alguns dos limites e possibilidades desse processo complexo de mediação simbólica, através da análise de um caso: o das práticas mágicas e do processo inquisitorial de Luzia Pinta. Não pretendo sugerir que ela tenha sido um exemplo típico de praticante de ritos mágicos na sociedade colonial, ou que, de alguma forma, sua trajetória pessoal possa ser estendida para a de outros africanos em outros contextos. Contudo, o que pretendo é partir do arranjo empírico dos repertórios simbólicos em uma situação determinada para apreender possibilidades e limites que se punham a esse processo na América Portuguesa. Se a cultura é algo situacional, que só se dá em contexto, ${ }^{4}$ então é justamente a análise minuciosa de um contexto que nos permitirá apreender o funcionamento das mediações simbólicas em jogo.

${ }^{4}$ GEERTZ, Clifford. "Uma Descrição Densa: Por uma Teoria Interpretativa da Cultura”. In: A Interpretação das Culturas. Rio de Janeiro: Jorge Zahar Editor, 1978, p. 13-41. 


\section{Historiografia das práticas mágicas afro-luso-americanas}

Luzia Pinta é uma velha conhecida dos estudos sobre práticas mágicas na sociedade colonial. Praticante de cerimônias mágico-religiosas denominadas "calundus", seu processo inquisitorial foi estudado em pelo menos três ocasiões diferentes, por Laura de Mello e Souza e Luiz Mott. ${ }^{5}$ Ambos estudaram as práticas mágicas na sociedade colonial com o objetivo de evidenciá-las como produtos sincréticos de trocas culturais ocorridas na sociedade colonial entre as culturas européia, africanas e ameríndias. Em especial, no que toca às práticas mágicas exercidas por africanos, os dois ressaltam que são expressões de sincretismo entre as religiões africanas, o catolicismo popular e, ocasionalmente, elementos das práticas ameríndias.

Laura de Mello e Souza, tendo primeiro visto nos calundus de Luzia Pinta um "proto-candomblé", ${ }^{6}$ mais tarde abandonou essa interpretação e propôs pensar neles (e especialmente no termo "calundu") como uma espécie de "nebulosa" que agregou um conjunto heterogêneo de práticas religiosas derivadas do universo simbólico bantu. ${ }^{7}$ Nisso, reconhecia o trabalho de Luiz Mott, que, numa análise etno-histórica de objetivo genético, determinou que a matriz cultural dos calundus de Luzia Pinta eram os rituais realizados por um tipo de sacerdote existente na África centro-ocidental do século XVII chamado xinguila. ${ }^{8}$ Ao mesmo tempo em que ressaltava a origem especificamente centro-africana dos ritos, porém, Mott também assinalava seu sincretismo com o catolicismo.

James Sweet, por outro lado, critica frontalmente a idéia de que as práticas mágicas dos africanos na América Portuguesa fossem expressões de sincretismo

\footnotetext{
${ }^{5}$ SOUZA, Laura de Mello. O diabo e a terra de Santa Cruz: Feitiçaria e religiosidade popular no Brasil colonial. São Paulo: Cia. das Letras, 1987; Idem. "Revisitando o calundu". In: GORENSTEIN, Lina e CARNEIRO, Maria L. Tucci (Org.). Ensaios sobre a intolerância: Inquisição, Marranismo e Anti-Semitismo. São Paulo: Humanitas, 2002, p. 293-317; e MOTT, Luiz. "O calundu-Angola de Luzia Pinta: Sabará, 1739". Revista do IAC, Ouro Preto, n. 1, p. 73-82, dez 1994.

${ }^{6}$ O diabo e a terra de Santa Cruz: Feitiçaria e religiosidade popular no Brasil colonial. São Paulo: Cia. das Letras, 1987, p. 352-357.

7 “Revisitando o calundu”. In: GORENSTEIN, Lina e CARNEIRO, Maria L. Tucci (Org.). Ensaios sobre a intolerância: Inquisição, Marranismo e Anti-Semitismo. São Paulo: Humanitas, 2002, p. 293-317.

8 “O calundu-Angola de Luzia Pinta: Sabará, 1739". Revista do IAC, Ouro Preto, n. 1, p. 7382, dez 1994.
} 
entre religiões africanas e o catolicismo. Pelo contrário, postulando uma absoluta incomunicabilidade entre este e aquelas, afirma que as práticas mágicas eram essencialmente um transplante, para o Novo Mundo, das religiões africanas, que teriam se mantido "intactas" em forma e função. ${ }^{9}$ A respeito dos calundus em especial, o autor afirma que o "calundú era a religião centro-africana em ação". ${ }^{10}$

Apesar de bastante breve, esta apresentação das hipóteses lançadas pelos três autores que se dedicaram com mais vagar ao estudo das práticas mágicas coloniais revela que há algo comum a todos: a centralidade da categoria de sincretismo. No caso de Mott e Souza, trata-se de confirmar a existência de sincretismo; no caso de Sweet, de negá-la. Malgrado os afastamentos, ambas as correntes partilham a noção fundamental de sincretismo como resultado da mistura de duas (ou mais) culturas. É preciso redimensionar essas análises a partir da crítica realizada ao conceito de sincretismo. Com efeito, como afirma Pierre Sanchis, ${ }^{11}$ ao se pensar em um produto cultural sincrético, presume-se necessariamente a existência de outros não sincretizados, ou "puros". O conceito de sincretismo parte do pressuposto inicial de uma "pureza cultural" anterior ao contato cultural e à mistura, como se as culturas pudessem ser tratadas como unidades ontológicas puras. Essa "pureza prévia” não pode ser outra coisa senão uma definição de caráter arbitrário, que essencializa uma cultura como estrutura estável e auto-referente, flagrada em um momento específico de sua dinâmica interna, momento este que é então alçado à categoria de imagem cristalizada daquela cultura.

Se, por outro lado, pensamos na cultura como contexto em que repertórios e tradições diferentes são incessantemente agenciados de forma situacional, relacional, de acordo com interesses específicos, é evidente que a idéia de uma cultura como unidade essencializada, fechada e ontológica (concepção herdeira do culturalismo norte-americano) não faz mais sentido. Neste caso, o foco da análise deixa de ser a descrição de uma realidade cultural dada (já que a cultura deixa de ser pensada como algo que pode ser descrito, e passa a ser encarada como polimorfa, em constante reelaboração) para atentar para os processos de agenciamento constante e de produção simbólica. Especificamente no caso de

\footnotetext{
${ }^{9}$ Recreating Africa: Culture, Kinship, and Religion in the African-Portuguese World, 14411770. Chapel Hill: University of North Carolina Press, 2003.

${ }^{10}$ Ibid., p. 151, minha tradução.
} 
análises de contatos entre sociedades diferentes, o que importa não é determinar se uma cultura "se mantém intacta" ou "se sincretiza", pois a idéia de uma cultura intacta simplesmente perde sentido. O que se coloca como tarefa para este tipo de abordagem da cultura é entender os processos de mediação simbólica que tornam possível a comunicação entre universos simbólicos, e de que forma essa mediação se vincula a interesses específicos. Neste estudo, tentarei apresentar uma nova interpretação das práticas de Luzia Pinta tendo esses objetivos em mente.

\section{A batalha pela palavra}

"Cinqüenta anos pouco mais ou menos, preta baça, alta e grossa de corpo, com um sinal mais perto da testa e em cada face outro". ${ }^{12}$ Com essas palavras, o escrivão do Tribunal do Santo Ofício da Inquisição de Lisboa descrevia a ré Luzia Pinta, que chegara a Lisboa em 18 de dezembro de 1742 para ser julgada pela Inquisição. Posta no cárcere, sua primeira confissão fora obtida em 18 de março do ano seguinte, e o julgamento estendera-se por mais de dois longos anos em que ela permaneceu encarcerada.

Com base em suas confissões, os inquisidores traçaram e registraram os detalhes de seu caso. Nascida em uma família de escravos em Luanda, na costa de Angola, fora embarcada como escrava para a América ainda pequena. Conquistara a alforria e residia em Sabará, nas Minas Gerais. Aparentemente, já fora alvo de denúncias anteriores e, após denúncia de dois vizinhos seus ao Comissário do Santo Ofício, foi aberto um Sumário de Culpas para averiguar seus crimes contra a fé católica. Após a coleta de dezenas de testemunhas e o envio das acusações a Lisboa, determinou-se que a suspeita fosse levada ao Tribunal para abertura do processo inquisitorial e julgamento.

Luzia Pinta foi acusada por ser "calunduzeira" em Sabará. O que eram, afinal de contas, essas cerimônias que realizava, os calundus? Feitiçaria, no bom português canônico que os inquisidores compreendiam? Uma das

\footnotetext{
11 "As tramas sincréticas da história: Sincretismo e modernidades no espaço luso-brasileiro". Revista Brasileira de Ciências Sociais, São Paulo: ANPOCS, ano 10, n. 28, p. 123-138, jul. 1995.

${ }^{12}$ Arquivo Nacional da Torre do Tombo, Inquisição de Lisboa, Processo $\mathrm{n}^{\circ} 252, \mathrm{~m}^{\circ} 26$. Apud. SOUZA, Laura de Mello. O diabo e a terra de Santa Cruz: Feitiçaria e religiosidade popular no Brasil colonial. São Paulo: Cia. das Letras, 1987, p. 352.
} 
testemunhas, Manuel Pereira da Costa, afirmava que sabia ser ela calunduzeira, mas não tinha certeza se era feiticeira.

O debate terminológico, que para nós, a princípio, parece ter interesse apenas marginal, no Tribunal do Santo Ofício de Lisboa transformou-se numa questão vital para Luzia Pinta e é a indicação de uma discussão que teria como objetivo adequar as práticas mágicas de Luzia Pinta aos padrões e estereótipos cunhados pela demonologia erudita pela qual se pautavam os inquisidores. Transformá-la de calunduzeira em feiticeira era o processo por meio do qual um discurso estrangeiro e incompreensível era traduzido para a linguagem eclesiástica e a alteridade era representada como projeção do imaginário do horror demonológico, atenuando a tensão e regenerando o discurso ameaçado de dissolução. As práticas desviantes podiam então ser apresentadas como manifestações das forças infernais, legitimando as reações de aversão e as ações repressivas.

No direito eclesiástico, a feitiçaria caía na jurisdição dos Tribunais do Santo Ofício na medida em que podia ser enquadrada como crime de heresia. Desde a bula papal Super illius specula, de 1326, havia precedentes para que as práticas mágicas, antes toleradas pela Igreja, caíssem sob essa acusação e fossem passíveis de perseguição. O que permitia enquadrar os feiticeiros como hereges e, portanto, colocá-los sob a jurisdição inquisitorial, era a noção de pacto demoníaco: para a teologia católica, os feiticeiros só conseguiriam realizar suas mágicas através da ajuda do Demônio. Essa ajuda presumiria um pacto do feiticeiro com as forças infernais: no caso de ser um acordo realizado com a anuência do feiticeiro, de forma consciente, era chamado de "pacto explícito". Caso contrário, se o feiticeiro não tivesse realizado nenhum acordo conscientemente, ainda restava o fato de que suas mágicas só poderiam ter sido realizadas com intervenção demoníaca. Presumia-se então, de acordo com Santo Agostinho, que teria havido um "pacto implícito", necessário para o sucesso das práticas mágicas. ${ }^{13}$

Criava-se assim uma poderosa ferramenta jurídica de acusação que podia ignorar as intenções declaradas do réu e encontrar o pacto mesmo onde ele não era confessado. Essa cadeia de argumentos teológicos que transformava o feiticeiro em herege imprimia-se sobre os interrogatórios a que a Inquisição submetia os acusados de feitiçaria, sugerindo uma série de questões relevantes

${ }^{13}$ CARDINI, Franco. Magia, brujería y superstición en el Occidente medieval. Barcelona: Ediciones Península, 1982. 
a serem feitas a fim de enquadrar o réu nos padrões e estereótipos criados pelos demonólogos. O discurso assumia uma forma monológica de argumento viciado, em que os inquisidores formulavam suas perguntas esperando escutar a confirmação dos próprios estereótipos que sugeriam as questões. Como afirma Carlo Ginzburg, "as respostas dos réus eram muito freqüentemente apenas um eco das perguntas dos inquisidores", ${ }^{14}$ estas orientadas de acordo com a imagem do discurso demonológico vigente. Não poderia ser diferente em uma prática discursiva cujo sentido era o de projetar as categorias de aversão e horror de um discurso para normalizar a tensão trazida pela alteridade. Para Ginzburg, quanto maior a distância entre as expectativas dos interrogadores e as respostas do réu, provavelmente mais perto se está de uma resposta que permita vislumbrar uma formulação do réu, e não uma projeção dos estereótipos inquisitoriais.

O feiticeiro se caracterizava, antes de mais nada, pelo pacto demoníaco. Logo se vê, portanto, que a transformação de Luzia Pinta de calunduzeira em feiticeira era um procedimento absolutamente vital para o sucesso da acusação, durante o qual as categorias e o imaginário do horror da cultura européia seriam projetados sobre Luzia Pinta. A ré apresentou uma seqüência de desafios conceituais a essa projeção dos estereótipos demonológicos. Em primeiro lugar, alegou que suas curas e adivinhações eram feitas por intermédio e por graça de Deus, reputando ainda seus feitos a Santo Antônio e São Gonçalo (a quem mandava dedicar missas com parte do dinheiro obtido com os rituais) e indicando a Virgem Maria como patrona de suas adivinhações.

Para dificultar a acusação, ainda restava saber se seus "calundus" eram uma espécie de feitiçaria. A princípio, a descrição que os denunciantes fizeram dos calundus apontava nesse sentido: vestida com trajes considerados inusitados (“à turquesa"), ela entrava em transe ao som de atabaques tocados por ajudantes negros, escravos seus, bebia vinho e começava a realizar adivinhações. Respondia às perguntas que lhe eram endereçadas pelos clientes, diagnosticava doentes prostrados ao chão e lhes ministrava remédios diversos, tudo isso por intermédio de uns "ventos de adivinhar" que lhe vinham pelos ouvidos.

\footnotetext{
${ }^{14}$ GINZBURG, Carlo. "O Inquisidor como Antropólogo". Revista Brasileira de História, São Paulo, v. 11, n. ${ }^{\circ}$ 21, p. 09-20, set. 90 / fev. 91, p. 14.
} 
Mas, se o calundu era uma cerimônia, a ré depois afirmou, provavelmente contrariando as expectativas e estereótipos dos inquisidores, que também era uma doença contagiosa de Angola e que era "destino" ou "virtude" concedidos por Deus. Luzia Pinta ainda tinha experiências extáticas: ia a muitos lugares enquanto seu corpo permanecia imóvel, como morto. Segundo ela, fazia-o com a ajuda de Deus.

Não obstante todas as tentativas, Luzia Pinta foi enredada pela lógica implacável da acusação inquisitorial: tendo ela admitido que sua "doença" era sobrenatural, os inquisidores puderam presumir que se tratava de intervenção demoníaca, uma vez que Deus não agia daquela forma, concedendo tais poderes divinatórios e permitindo que as almas deixassem os corpos em vida para depois retornarem. Ante isso tudo, os inquisidores concluíram que só podia se tratar de intervenção diabólica, que presumia um pacto implícito entre o demônio e a ré, que agora podia sem hesitações ser considerada feiticeira.

No hiato entre a declaração a respeito de calundus e o enquadramento dessas cerimônias (ou dessa doença?) na categoria de feitiçaria, observamos uma batalha discursiva desigual, travada de posições de poder absolutamente assimétricas, na qual o discurso de Luzia Pinta vai dando lugar ao discurso demonológico da Inquisição. Após um longo embate de mais de dois anos, o triunfo da leitura demonológica foi também o fechamento do processo, já que foi a partir das categorias desse discurso eclesiástico - feitiçaria, apostasia, pacto - que a acusada se configurou como culpada.

\section{Percursos iniciáticos}

É evidente no caso de Luzia Pinta como a Igreja, através dos tribunais do Santo Ofício, empregava uma estratégia bastante específica de mediação cultural, fechando-se a uma enunciação dialógica e adotando um procedimento de projeção das categorias do discurso eclesiástico, engendrando não apenas a fixação da alteridade nas formas prefiguradas pela tradição, dando escape às tensões do discurso colonial, como também servindo de sustentáculo a práticas discriminatórias na sociedade colonial através da preservação de um discurso coeso. No entanto, Luzia Pinta, a personagem central deste estudo, ainda está ausente, legada ao silêncio. É preciso tentar desvendar as suas próprias estratégias de mediação simbólica com a cultura católica, a forma como ela articulou sua experiência em Angola e na América na criação de seus calundus, enfim, tentar reconstruir analiticamente o que pode ter sido uma forma através da qual Luzia 
Pinta organizou discursivamente sua experiência e mobilizou os repertórios culturais à sua disposição.

Como ressaltado, Mott empreendeu uma análise etno-histórica da descrição dos calundus de Luzia Pinta presente no processo inquisitorial e, comparandoa com os relatos elaborados no século XVII pelo missionário João António Cavazzi de Montecúccolo a respeito do Congo e de Angola, determinou uma filiação genética para os rituais de Luzia Pinta nos rituais dos xinguilas de Angola, descritos por Cavazzi, ainda que Luzia Pinta tenha incluído no ritual "traços de outras 'castas de feiticeiros' de sua terra natal [e] [...] vários elementos do catolicismo". ${ }^{15}$ Não pretendo aqui reproduzir todos os passos da análise de Mott, e muito menos negar a existência dos laços que ele identificou entre os calundus de Luzia Pinta e as práticas mágicas centro-africanas. Contudo, não é esta genética do sincretismo o que mais nos interessa aqui, mas sim o desvendamento dos processos simbólicos de mediação cultural e de agenciamento diferencial das tradições simbólicas.

Voltemos nossa atenção a um trecho da documentação que não recebeu ainda a atenção devida. Num determinado ponto do interrogatório, após a declaração aparentemente extravagante de que os calundus seriam uma doença, Luzia Pinta foi questionada pelo inquisidor: "Que doença é esta da sua terra, a quem chamam calundus, de que cousa procede, que efeitos produz e por quais sinais se reconhece?". ${ }^{16}$ A esta pergunta, segundo o escrivão, Luzia Pinta

Disse que a respeito do conteúdo da pergunta só sabe declarar que a dita doença lhe chamam na sua terra calundus e que esta se pega de umas pessoas a outras e que a ela lha poderia ter comunicado uma tia sua, chamada Maria, o que não sabe ao certo, por ter vindo de mui tenra idade. E o que pode afirmar com certeza é que achando-se ela na vila de Sabará ouvindo missa em dia santo, lhe sobreveio repentinamente a dita doença, de que ficou muito mal, por não saberem os remédios que se

\footnotetext{
${ }^{15}$ MOTT, op.cit., p. 81.

${ }^{16}$ Apud. MOTT, op. cit., p. 75. Todos os excertos do processo de Luzia Pinta transcritos aqui foram extraídos deste artigo de Mott, onde se encontram transcritos alguns trechos da documentação inquisitorial.
} 
haviam de aplicar, até que sendo chamado um preto por nome Miguel, escravo de Manuel de Miranda, morador na dita vila, lhe disse este que a dita queixa era a do calanduz e que só a havia de curar e ter remédio mandando tocar alguns instrumentos e fazendo [algumas coisas] mais, por ser este o meio e o modo porque se costuma curar a dita doença, o que com efeito ela fez e experimentou melhora. ${ }^{17}$

O excerto narra a forma como Luzia Pinta, após um desfalecimento ao ouvir a missa, passou a realizar, ela própria, ritos mágicos em Sabará. Qual a relação entre essa forma e aquelas vigentes em Angola, de onde Luzia Pinta viera?

Retomemos alguns dos aspectos das tradições mágico-religiosas vigentes entre os séculos XV e XIX nas sociedades bantu da África centro-ocidental. Nelas, o sacerdote era um mediador entre o mundo visível, habitado pelos vivos, e o mundo invisível, habitado pelos espíritos e pelos antepassados. Em geral, para um indivíduo se tornar sacerdote ou chefe (ambos eram títulos com funções rituais), ele era iniciado no culto de um espírito específico. Mediante uma cerimônia em que pagava uma taxa variável de acordo com o título, o candidato era geralmente levado a uma reclusão ritual, de onde saía algum tempo depois possuidor de segredos e poderes sobre o espírito em questão. Essa reclusão, em nível simbólico, correspondia a uma morte ritual, uma passagem para o mundo invisível dos espíritos, de modo que, ao término dela, o iniciado voltava ao mundo visível dos vivos portando características e poderes especiais - um carisma religioso, em termos weberianos. A partir daí, podia, ele próprio, realizar rituais e cobrar pelos serviços. ${ }^{18}$ Aparentemente, o processo por que passou Luzia Pinta é completamente diverso, indicando a apropriação de uma outra lógica de iniciação ritual. Contudo, destrinchando os fios da narrativa, veremos surgir uma lógica muito semelhante.

Primeiramente, notemos alguns aspectos que podem nos dar mais informações a respeito do contexto social e cultural em que os fatos transcorreram. A passagem da utilização do termo calanduz, como o preto Miguel chamava a doença, para calundu provavelmente atesta que o último era um termo em

\footnotetext{
${ }^{17}$ Apud. MOTT, op. cit., p. 75.

${ }^{18}$ MACGAFFEY, Wyatt. Religion and Society in Central Africa: The BaKongo of Lower Zaire. Chicago/London: The University of Chicago Press, 1986, p. 107-113.
} 
circulação na região na época, palavra que provavelmente Luzia Pinta ainda ouviria da boca de outros antes que fosse transmitida, em denúncia, ao Santo Ofício. Vemos aí uma indicação de que nem Luzia Pinta e nem mesmo Miguel representavam um fenômeno isolado, e de que deveria haver na região outros africanos que conhecessem e praticassem cerimônias chamadas calundus.

James Sweet sugere convincentemente que o termo calundu derive do vocábulo angolano quilundu, "um nome genérico para qualquer espírito que possuísse os vivos". ${ }^{19}$ Como o autor ressalta, espíritos podiam possuir o corpo de um indivíduo por inúmeros motivos, entre os quais a falta de respeito ou veneração adequada, no caso de espíritos de ancestrais. Como outros calundus coloniais, as cerimônias de Luzia Pinta contavam com a sua possessão ritual por espíritos, por meio dos quais ela fazia adivinhações e curas - como, de resto, era comum na tradição centro-africana, como atestam tanto a etnografia de Wyatt MacGaffey ${ }^{20}$ quanto os relatos de Cavazzi. ${ }^{21}$

A falta de respeito não é a única ocasião na qual um espírito podia possuir e fazer adoecer um descendente seu. O mesmo podia ocorrer no início de um processo de iniciação ritual: um espírito ancestral (nkulu, em kikongo) podia decidir possuir e afligir um descendente como forma de "propor" uma comunhão e um adensamento de laços recíprocos entre o ancestral e seu descendente (laços que podiam inclusive estar sendo negligenciados pelo último). Procurando tratamento ritual adequado, o doente livrava-se da enfermidade e passava a ter uma ligação especial com o espírito que antes o possuíra. Com isso, tornando-se um elo de mediação entre mundo visível e invisível, ele passava a poder mobilizar o poder do espírito para diversos fins rituais, tornando-se um oficiante dos cultos desse espírito. ${ }^{22}$

Ora, parece bastante semelhante o que ocorreu com Luzia Pinta, como já o sabia o preto Miguel, que a auxiliou na cura: acometida de uma doença ou aflição espiritual, ela foi tratada e tornou-se também uma especialista de ritos mágicos. O palpite de Luzia Pinta de que a doença lhe fora transmitida pela

\footnotetext{
${ }^{19}$ SWEET, op. cit., p. 144, minha tradução.

${ }^{20}$ Op. cit.

${ }^{21}$ CAVAZZI DE MONTECÚCCOLO, Padre Giovanni António. Descrição histórica dos três reinos do Congo, Matamba e Angola. Lisboa: Junta de Investigações do Ultramar, 1965. 2 v.

${ }^{22}$ MACGAFFEY, Wyatt, op. cit.
} 
tia não é fortuito: como uma aflição espiritual referente à relação entre uma linhagem e seus ancestrais, a "doença" estava ligada a relações de parentesco e se dava no interior de uma linhagem. Luzia Pinta, ainda pequena, teria então sido acometida de uma aflição ligada aos espíritos da linhagem, aflição esta que se manifestou novamente na América e foi curada por meios rituais. Esta cura, restabelecendo a ligação de Luzia Pinta com o ancestral, adensando os laços entre as partes, permitiu que ela derivasse desta ligação um carisma religioso para realizar ritos mágicos.

Isto sugere que Miguel fosse também um curandeiro. Novamente, a documentação sustenta esta hipótese: como ninguém soubesse o que sucedera a Luzia, Miguel fora chamado especialmente para o caso. Suponho que a escolha do homem para tratá-la não tenha sido casual: por que procurar Miguel, que não presenciara a cena, e não qualquer outra pessoa mais próxima? Nas entrelinhas dessa convocação lemos justamente o reconhecimento geral de que Miguel era um homem possuidor do conhecimento necessário para curar Luzia de uma enfermidade espiritual. Ora, essa era a atribuição dos mágicos, de modo que é provável que Miguel fosse, ele também, um praticante de magia, ou que ao menos tivesse familiaridade com os procedimentos rituais centro-africanos (possivelmente por intermédio de outros feiticeiros locais). Como era costume na colônia, é muito possível que alguém tenha pago a Miguel a soma em dinheiro devida para que ele executasse a cura de Luzia Pinta.

Após ter se curado da doença causada pelos espíritos, ela própria pôde ter acesso a eles como meios de realizar curas e adivinhações em seus calundus. $\mathrm{O}$ que temos aqui, em linhas gerais, é o padrão de uma iniciação mágica centroafricana: após ser afligida por um espírito, ela recebeu tratamento ritual adequado (da parte de Miguel) e, possivelmente mediante o pagamento de uma taxa (o dinheiro devido a Miguel - neste ponto, as restrições advindas das parcas possibilidades de acúmulo de bens por parte dos escravos deve ter influenciado no sentido de amenizar tais necessidades na América), iniciou-se num culto do qual, uma vez curada, tornou-se ela própria uma especialista.

Contudo, a iniciação de Luzia Pinta não contempla, até aqui, todos os aspectos das iniciações rituais centro-africanas. Está faltando um elemento muito importante: a reclusão, a morte ritual que acompanhava as iniciações mágicas e que representava o contato do iniciado com os espíritos no mundo dos mortos. Igualmente, faltam referências claras à ligação de Luzia com um espírito ancestral. Vamos encontrar ambas as coisas, no caso de Luzia Pinta, antes da travessia do Atlântico, ainda em Angola. Vejamos um outro trecho da 
documentação, no qual Luzia Pinta relata um acontecimento ocorrido durante sua infância, em Luanda:

Aos 12 anos, pouco mais ou menos, assistindo na cidade de Angola, em casa de seu senhor Manoel Lopes de Barros, saindo um dia pela manhã ao quintal das casas em que morava, caiu repentinamente como morta no meio dele, e ficando totalmente imóvel e privada de seus sentidos, foi levada sem saber como, até a margem de um grande rio aonde encontrando uma velha, lhe perguntou esta para que parte ia, e respondendo-lhe ela declarante que não sabia, lhe continuou a dizer a dita velha que fosse muito embora porque logo havia de voltar. E continuando com efeito o seu caminho, encontrou mais acima um homem ainda moço que lhe fez as mesmas perguntas e ela lhe deu as mesmas respostas e andando mais encontrou outra velha que lhe perguntou para que parte queria ir, e respondendo-lhe que queria passar para outra banda do rio, lhe disse então a mesma velha que pegasse na ponta de uma linha bem fina que tinha na mão e conseguiria o que desejava. E fazendo-o ela assim, sucedeu secar repentinamente o dito rio, de sorte que pôde passá-lo enxuto e sem embaraço algum. E dando logo a uma encruzilhada, encontrou com outras duas velhas e com dois caminhos, um muito sujo e outro muito limpo, e intentando ela ir por este, lhes disseram as ditas velhas que havia de ir pelo sujo, se quisesse ou não. E indo com efeito por ele, chegou a uma casa grande a onde um homem ancião com barbas compridas, assentado em uma cadeira, e de redor dele, vários meninos com cadeiras avezas. E querendo ela deitar-se, chegou ao pé do dito homem, a quem tomou a bênção, e logo este lhe disse que fosse embora, sem passar mais cousa alguma. E vindo já na escada daquelas casas, retirando-se, sucedeu tornar a si por virtude de remédios e fumaças que o dito seu senhor lhe mandou fazer pela achar como morta no dito quintal. E dando depois conta de tudo a um clérigo, o padre Manuel João, assistente na mesma cidade de Angola, lhe disse este que aquele velho ancião era Deus, Nosso Senhor, o que ficou ela assim entendendo pela referida razão, e não passou mais cousa alguma nem teve outra visão. ${ }^{23}$

${ }^{23}$ Apud. MOTT, op. cit., p. 74-75. 
A rigor, a iniciação de Luzia começou antes de ela ser traficada para a América, embora pudesse ter permanecido apenas como potencial. A "iniciação" de Miguel desenvolveu essa potencialidade que já estava latente. Analisemos a narrativa de Luzia Pinta a respeito do desfalecimento em sua infância.

Nela, apresenta-se a mesma estrutura que vemos nos mitos de origem dos clãs no Congo, como relata MacGaffey: um ancestral que atravessa um grande rio (o Nzadi, ou rio Zaire, no caso dos mitos de fundação dos bakongo) e se estabelece em uma localidade. O rio tinha um lugar bastante importante na simbologia centroafricana. Como se ressaltou, a tradição cosmológica centro-africana concebia o universo como dividido em duas metades: um mundo visível habitado pelos vivos e um mundo invisível habitado pelos espíritos e pelos mortos. Os dois mundos estabeleciam entre si relações ao mesmo tempo de oposição, complementaridade (dentre as quais as relações entre sacerdotes e espíritos) e especularidade. A fronteira que separava os mundos era representada por um conjunto de símbolos tidos como transitórios, especialmente a água, o rio e a cor vermelha.

Assim sendo, a passagem do rio nos mitos de origem dos clãs do Congo é portanto uma travessia cósmica entre os mundos, o que confere ao ancestral fundador poder especial e legitimidade. Ao penetrar o mundo dos espíritos, o ancestral se tornava mediador privilegiado entre os vivos e os espíritos, e assim adquiria poder. Trata-se de uma representação mítica da mesma iniciação por que passavam chefes e sacerdotes.

Quando Luzia Pinta desfaleceu, sua alma dirigiu-se diretamente à beira de um rio. A princípio, ela hesitou, talvez consciente da natureza da fronteira cósmica que estava à sua frente, mas, para a terceira velha, disse que desejava atravessar o rio. Do outro lado, encontrou mais duas velhas que guardavam uma bifurcação de caminho, um deles limpo e outro sujo.

A oposição limpo-sujo pode ser lida como correspondente, do ponto de vista estrutural, a outra oposição fundamental das cosmologias centro-africanas: aquela entre a vila, residência dos vivos estabelecida na clareira aberta na floresta, e o túmulo, morada dos ancestrais, localizado na floresta. Se a oposição limpo-sujo pode ser relacionada a clareira-floresta (sobretudo no contexto de uma narrativa em que limpo e sujo se aplicam a dois caminhos que atravessam o terreno natural), então também pode ser reduzida a mundo visível-mundo invisível e a vida-morte. Podemos interpretar a visão de Luzia como se o caminho limpo, que ela dizia pretender tomar, representasse uma volta à vila, terreno limpo na floresta, e o caminho sujo, o qual as velhas aconselham Luzia a seguir, 
representasse a passagem para o mundo invisível, a morte simbólica. $\mathrm{O}$ ato de escolher o caminho sujo seria assim uma duplicação, um reforço do sentido de atravessar o rio. Ao tomar o caminho indicado, ela ultrapassaria de uma vez por todas a fronteira entre os mundos e adentraria o terreno de uma morte simbólica, elemento constante tanto nas iniciações rituais quanto nos mitos centro-africanos.

A escolha entre os dois caminhos ainda podia ser tomada como significativa para a tradição católica. A temática da escolha é uma das constantes da tradição judaico-cristã e é encontrada já no Antigo Testamento, por exemplo, em passagens como a de Abraão, que precisa escolher entre seu filho e a obediência a Deus. Esse topos é reiterado de várias maneiras nas narrativas judaico-cristãs, e podemos vê-lo formulado claramente, sob a forma da escolha entre os dois caminhos, no Evangelho de Mateus: "Entrai pela porta estreita, pois larga é a porta e espaçosa a senda que leva à perdição, e muitos os que por ela entram. Quão estreita é a porta e apertado o caminho que leva à vida, e poucos os que o encontram!". ${ }^{24}$

A porta estreita e o caminho apertado correspondem aos sofrimentos, à abnegação, à abstenção e à penitência que se esperam do comportamento do bom cristão na Terra, para que ele possa gozar da vida eterna. Escolher o caminho mais difícil é abdicar dos confortos que se podem acumular e da satisfação dos desejos no mundo material em prol de alcançar a salvação. A porta larga e a senda espaçosa, por sua vez, correspondem a uma vida de pecados e de gozo das benesses do mundo terreno. Na tradição cristã, o tema da escolha ganha contornos bastante definidos: a oposição porta larga-porta estreita relaciona-se a facilidadedificuldade do caminho, de acordo com o ideal de uma vida de sacrifício. Assim, constituiu-se neste lugar comum a oposição entre um caminho fácil e um caminho difícil, com a valorização deste último como meio de obtenção da salvação.

Vamos encontrar esse topos representado de diversas maneiras na tradição católica, sempre remetendo simbolicamente a esta mesma oposição de termos "facilidade-dificuldade", e sempre com a valorização do último. A tradição hagiográfica é pródiga nessa representação: São Francisco, por exemplo, é constantemente instado a fazer uma escolha entre, por um lado, o conforto material e o orgulho e, por outro, a abnegação e a humilhação, e sempre escolhe a última. Por exemplo:

24 "Evangelho segundo São Mateus. Português". In: Bíblia Sagrada. Trad. Domingos Zamagna et alii. Petrópolis, RJ: Vozes, 1982. 
Ele preferia ouvir insultos que louvores, e quando as pessoas exaltavam os méritos de sua santidade, ordenava a algum irmão que proferisse aos seus ouvidos palavras aviltantes. E quando o irmão, muito a contragosto, chamava-o de rústico, mercenário, inábil e inútil, ele dizia, todo alegre: 'Que o Senhor o abençoe por dizer coisas tão verdadeiras e mais convenientes de ouvir'. ${ }^{25}$

Como último exemplo, o mesmo topos aparece na vida de São Domingos, fundador da ordem dos dominicanos:

Eleito bispo, segundo alguns de Copuserans, segundo outro de Comminges, recusou, afirmando preferir morrer do que aceitar. Perguntado certa vez por que gostava mais de ficar na diocese de Carcassone do que em Toulouse e na diocese tolosana, respondeu: 'Porque na diocese de Toulouse encontro muitas pessoas que me honram e na de Carcassone muitos que, ao contrário, me combatem'. ${ }^{26}$

Nos dois casos vemos, mais uma vez, a dicotomia entre um caminho agradável que leva à soberba, aos excessos e ao pecado, e outro, difícil, que leva à virtude por meio da provação e do sofrimento. Essa representação, constante na tradição cristã, pode ter fornecido uma chave a partir da qual é igualmente possível interpretar a bifurcação, na visão de Luzia Pinta, entre o caminho limpo e o caminho sujo. A escolha da menina pelo segundo, aconselhada pelas velhas e vencendo a tentação inicial de percorrer o limpo, pode então ser lida como a escolha de um caminho de virtude.

Lembremo-nos de que, após acordar de sua visão extática, Luzia Pinta contou-a a um clérigo: "E dando depois conta de tudo a um clérigo, o padre Manuel João, assistente na mesma cidade de Angola, lhe disse este que aquele velho ancião era Deus, Nosso Senhor, o que ficou ela assim entendendo pela referida razão, e não passou mais cousa alguma nem teve outra visão". ${ }^{27}$ É

\footnotetext{
${ }^{25}$ DE VARAZZE, Jacopo. Legenda áurea: vidas de santos. São Paulo: Companhia das Letras, 2003, p. 844.

${ }^{26}$ Ibid., p. 626.

${ }^{27}$ Apud. MOTT, op. cit., p. 74-75.
} 
provável que o padre tenha interpretado a bifurcação da visão da menina a partir dessa simbologia dos caminhos da tradição cristã, adequando sua visão ao universo religioso do catolicismo.

Estamos, portanto, diante de uma visão que pode ser interpretada tanto a partir da tradição centro-africana quanto da católica, com sentidos distintos: no primeiro caso, representando uma morte ritual para a obtenção de uma ligação especial com os espíritos; no segundo, representando a escolha da virtude e a negação do pecado, em direção à salvação. Como a própria Luzia Pinta a teria interpretado? Conscientemente, é provável que não tivesse clareza de nenhum dos dois conjuntos simbólicos que podiam ser associados à bifurcação, ainda mais tendo em vista a tenra idade. Porém, é igualmente provável que já tivesse tido contato, mesmo que indireto (através de mitos, narrativas, experiências rituais etc.) tanto com as religiões tradicionais centro-africanas como com o catolicismo, e sua visão podia se mover entre esses dois terrenos.

Temos uma unidade semântica fundamental que é a de um indivíduo que escolhe entre dois caminhos, presente tanto na mitologia centro-africana como na mitologia católica, que pode ser inserido significativamente em duas séries distintas de narrativas míticas. Por um lado, pode ser um signo correspondente a um mito de fundação ou a uma iniciação ritual centro-africana; por outro lado, pode corresponder ao topos cristão da escolha e à série mítica das hagiografias católicas. Assim sendo, a narrativa de Luzia Pinta podia ser convenientemente interpretada como uma variante tanto dos mitos de fundação e iniciações bantu quanto das hagiografias católicas, dependendo da interpretação dada. Penso que, neste contexto multicultural no qual Luzia estava inserida desde o início de sua vida, seu "mito pessoal" poderia ser alocado a séries míticas distintas, de acordo com a situação, com a tradição cultural com a qual escolhesse dialogar em um dado momento, com os contextos e estratégias de ações e com as suas intencionalidades pragmáticas. Numa aproximação com a tradição católica, Luzia Pinta poderia se auto-interpretar (e ser interpretada) como uma variante de uma narrativa hagiográfica; numa aproximação com a cultura de seus antepassados, como uma variante de uma narrativa de fundação dos ancestrais e de iniciação ritual.

Cada possibilidade poderia ser adensada diferencialmente em situações diferentes, dando origem a diálogos e aproximações com horizontes simbólicos distintos. Essa possibilidade de adensamento diferencial do diálogo com uma certa tradição se evidencia de forma muito clara em um dado momento do processo, em que o escrivão registrou que a acusada "Disse mais, que tudo 
fazia por destino que Deus lhe deu, e por esta causa é que ela diz e assevera nas ditas ocasiões que lhe vêem os ventos de adivinhar, que Deus Nosso Senhor é que lhe diz o que há de fazer". ${ }^{28}$ Isso que Mott interpretou como uma "astúcia" de Luzia Pinta revela-se sob essa perspectiva como uma escolha, orientada por interesses bastante concretos de escapar da punição, de uma leitura possível de sua narrativa pessoal através das lentes da tradição católica. Não se trata de uma enganação, mas de um posicionamento circunstancial no seio de uma tradição que sempre se apresentou como possibilidade de leitura.

Voltando à visão extática e interpretando-a de acordo com os códigos simbólicos das culturas centro-africanas, Luzia Pinta, depois de escolher o caminho sujo, adentrou o mundo espiritual e encontrou uma grande casa onde viviam alguns meninos e um velho ancião. Para o padre, interpretando a narrativa na chave católica, era evidente que o ancião era Deus, dando um fechamento mais do que adequado a essa visão divina; para a menina, contudo, dialogando com a tradição centro-africana, o ancião possivelmente evocava ainda figuras dos antepassados, os mesmos bakulu (plural de nkulu) que freqüentemente demandavam iniciações rituais por meio de aflições físicas e espirituais. Tendo tomado a bênção do ancião, Luzia foi embora e voltou ao mundo visível dos vivos.

É aqui que podemos encontrar sua morte simbólica: tendo ido ao mundo invisível e voltado, ela adquiriu uma conexão com os espíritos, e mais especificamente com o espírito do velho que a acolheu na casa. A iniciação ritual propriamente dita, quando ela seria introduzida nos serviços rituais e aprenderia a fazer uso dessa sua conexão, só se completaria em Sabará, aos cuidados do preto Miguel, mas suas raízes estavam neste episódio da infância, do qual Luzia se lembra não sem razão quando questionada pelos inquisidores.

Note-se que mesmo o desfalecimento de Luzia Pinta em Sabará está carregado dessa dupla interpretabilidade: se por um lado ela desfaleceu como que acometida por uma aflição espiritual causada por um nkulu (na leitura de acordo com a tradição ritual centro-africana), por outro lado ela o fez durante uma missa, remetendo igualmente aos êxtases místicos tão comuns na religiosidade barroca (numa leitura segundo a tradição católica).

${ }^{28}$ Apud. MOTT, op. cit., p. 78. 
Através da tradição centro-africana, Luzia podia interpretar que tinha uma conexão espiritual com seu nkulu, seu antepassado; pelas lentes da tradição católica do padre, pôde se convencer de que tinha uma conexão com o próprio Deus de quem recebera uma mensagem e que, segundo ela, era responsável por seus dons. Dependendo do contexto e do objetivo, podia atualizar, dar enfoque, a uma ou outra interpretação, ou equiparar as duas. Como se vê, no universo simbólico pessoal de Luzia Pinta, que ela colocaria em ação nos seus calundus em Sabará, promoveram-se leituras recíprocas entre as tradições centro-africana e católica, criando espaço tanto para os espíritos ancestrais quanto para o Deus católico, ambos simultaneamente fontes de seus poderes mágicos. Não há aqui a necessidade de escolha exclusiva entre duas cosmologias contraditórias: há sim a elaboração de um repertório simbólico que podia ter alguns de seus laços adensados de acordo com as circunstâncias na economia das estratégias simbólicas.

Uma vez na América Portuguesa, Luzia Pinta adensou laços simbólicos de acordo com suas necessidades de posicionamento na sociedade colonial. Ao lidar com outros escravos centro-africanos, podia invocar a legitimidade de uma mediadora entre os espíritos e os vivos como fonte de poderes mágicos e sustentáculo de sua atividade profissional. Embora não pudesse ser propriamente uma sacerdotisa centro-africana em uma sociedade sem as linhagens e relações sociais que dão suporte às práticas religiosas encontradas na África centro-ocidental, podia ao menos fazer referências às concepções cosmológicas de seus conterrâneos e tecer uma representação de sua fonte de poder. Ao mesmo tempo, podia invocar a sua conexão com Deus como signo de poder frente a população católica, inserindo-se no circuito das práticas e agentes do catolicismo mágico popular. ${ }^{29}$ A dupla interpretabilidade lhe conferia pois uma dupla legitimidade. A partir dessas estratégias, portanto, Luzia Pinta compunha um itinerário de produção simbólica que lhe permitia adentrar o universo cultural do catolicismo (mesmo que no espaço marginalizado da religiosidade popular), único legitimado pelos poderes institucionais na sociedade colonial, ao mesmo tempo em que resgatava e atualizava aspectos de sua cosmovisão centro-africana

\footnotetext{
${ }^{29}$ A respeito dessa tradição do catolicismo mágico popular, ver BETHENCOURT, Francisco. O imaginário da magia: feiticeiras, saludadores e nigromantes no séc. XVI. Lisboa: Projecto Universidade Aberta, 1987.
} 
e interpretava o catolicismo a partir deles. Tratava-se, portanto, de uma inclusão simbolicamente negociada.

\section{Continuidades e rupturas}

Voltemos à análise que Luiz Mott faz do calundu de Luzia Pinta para avançar em alguns outros pontos à luz da comparação com o relato do missionário capuchinho João António Cavazzi de Montecúccolo, que atuou em meados no século XVII na África centro-ocidental. O missionário capuchinho fez uma série de descrições de um certo tipo de "feiticeiro" que ele chama de "xinguila" (ora aportuguesando o plural da palavra, adicionando "S", ora referindo-se ao plural sem o "S" - escolherei aqui a forma plural aportuguesada). Mott recorreu a esta fonte, selecionando descrições dos rituais dos xinguilas e comparandoas com elementos do calundu de Luzia Pinta, determinando assim que seus rituais tinham origem nos dos xinguilas. Para isso, Mott destacou alguns aspectos da descrição que Cavazzi fez dos xiguilas e que encontramos na descrição do calundu de Luzia Pinta: o fato de que os xinguilas podiam pertencer ao sexo feminino, o fato de os clientes se deitarem no chão, o uso de um alfanje, um machadinho, grinaldas de flores e penachos, argolas e correntes de ferro e embrulhos com certos ingredientes atados aos braços dos clientes.

Com esse recorte, porém, Mott deixou de lado boa parte das descrições do missionário, sobretudo nos aspectos que não coincidiam com as práticas de Luzia Pinta. Longe de considerar esses aspectos como "perdas" ou "degenerações" culturais, pretendo dar a eles mais atenção, como forma de traçar o processo de mediação que levou à elaboração da forma final dos calundus de Luzia Pinta em Sabará. Essas rupturas podem revelar tanto sobre o processo quanto as continuidades.

Cavazzi definiu os xinguilas como um tipo de sacerdote dos jagas (como os portugueses chamavam o grupo cultural dos imbangalas). Mais especificamente, "xinguila quer dizer 'adivinho possuído por um espírito que fala pela sua boca", 30 ou seja, um adivinho que realiza seus ritos por meio de uma pos-

\footnotetext{
${ }^{30}$ CAVAZZI DE MONTECÚCCOLO, Padre Giovanni António, op. cit., Livro Segundo, § 50, p. 204. Note-se que os excertos transcritos por Luiz Mott no artigo supra-citado não coincidem exatamente com a redação da edição consultada neste estudo, muito embora a bibliografia indique a mesma edição. Não posso determinar o motivo dessa discrepância.
} 
sessão espiritual. Sob esta rubrica de "xinguila", na verdade, Cavazzi inclui um número de adivinhos diferentes entre si, como se pode observar na seguinte passagem: "Duas coisas há de comum com_todas as espécies de xinguila e de ídolos: a primeira é que, como cada província tem os seus ídolos particulares, os xinguila deputados ao culto deles têm sempre o nome do respectivo ídolo, além do nome genérico de quilundo". ${ }^{31}$ Assim, os elementos que Mott recolhe como característicos dos xinguilas podem não ser procedimentos exclusivos de um único tipo de sacerdote, mas uma coleção de procedimentos pertencentes ao que o olhar de Cavazzi identifica como um grupo de especialistas do sagrado, um grupo relativamente heterogêneo que continha especialistas em espíritos distintos. É possível que essas diferentes "espécies" de xinguilas compartilhassem entre si alguns ou todos esses procedimentos, como um repertório de práticas comuns, ainda que nem todas fossem necessariamente usadas por cada adivinho.

Além dos elementos do calundu de Luzia Pinta advindos dos xinguilas, Mott destaca outros pertencentes aos rituais de um tipo de sacerdote chamado "ngombo": o ato de urrar e saltar em transe, lançar pós sobre os clientes e dar-lhes vomitórios. A origem geográfica do ngombo não é precisada por Cavazzi, mas não se pode admitir a priori que coincida com a dos xinguilas. Assim sendo, o ritual de Luzia Pinta, antes de ser a recriação ipsis literis de um rito africano de um sacerdote específico, parece o resultado de seleção, apropriação e colagem de elementos oriundos dos ritos de sacerdotes diversos, talvez mesmo de regiões diferentes.

No âmbito das relações sociais e de prestígio também se revelam descontinuidades significativas entre Luzia Pinta e os xinguilas. Cavazzi deixa bastante claro o papel de proeminência social e política dos xinguilas entre os imbangalas:

Xinguila quer dizer 'adivinho possuído por um espírito que fala pela sua boca'. Esta ralé, a mais pestífera entre todas, é numerosíssima e muito estimada pelos Pretos, quer jagas, quer de outros povos. Embora se julguem isentos de qualquer lei, são rigorosíssimos contra os outros transgressores. Tudo o que eles mandarem deve ser cumprido, como se fossem deuses na Terra. São tão temidos que ninguém, nem sequer os príncipes, se atreve a falar-lhes senão de joelho dobrado e com suma reverência. [...] Ordinàriamente o fenómeno manifesta-se em pessoas importantes. ${ }^{32}$

\footnotetext{
${ }^{31}$ Ibid., Livro Segundo, § 58, p. 209 (o grifo é meu, os itálicos são da edição consultada).

${ }^{32}$ Ibid., Livro Segundo, § 50, p. 204 (os itálicos são da edição consultada).
} 
Mais adiante:

Estes xinguila gozam de uma autoridade formidável perante os reis e os comandantes dos exércitos. Poderiam ser, de certo modo, comparados com os capelães das nossas tropas, mas têm muito mais autoridade, pois são árbitros das determinações de ordem militar, especialmente quando seu êxito é mais difícil e incerto. ${ }^{33}$

O elevado status social possuído pelos xinguilas revela a importância da dimensão ritual na constituição do poder político nas sociedades centro-africanas. Podemos ver no relato de Cavazzi que estes sacerdotes constituíam um grupo muito próximo dos chefes políticos. Eram possivelmente semelhantes à figura, descrita por MacGaffey, do sacerdote que oficiava um culto de espíritos locais (bisimbi ou min'kisi nsi, em kikongo), um especialista do sagrado servindo a fins coletivos ligados ao poder dos chefes, chamado de nganga mbangu ou nganga kitomi ${ }^{34} \mathrm{~A}$ hipótese de que os xinguilas seriam sacerdotes de espíritos locais, ligados portanto aos poderes políticos nas sociedades centro-africanas, é reforçada por um outro indício que nos dá Cavazzi: "como cada província tem seus ídolos, os xinguila deputados ao culto deles têm sempre o nome do respectivo ídolo". ${ }^{35}$ Esses ídolos de cada província não são senão espíritos de caráter local (que em kikongo são chamados de bisimbi ou min'kisi nsi).

Com base nisso, podemos aventar a hipótese de que os xinguilas fossem, entre os imbangalas, sacerdotes oficiantes de espíritos locais, com poderes de caráter público, socialmente legitimados e ligados ao poder político. Bem distinta da situação em que se encontrava Luzia Pinta em Sabará. Lá, não havia poder político que se sustentasse em aliança com adivinhos de espíritos locais. A posição social de Luzia não era nem minimamente comparável à dos xinguilas; talvez pudesse ser aproximada da figura do curandeiro centro-africano que atendia a clientes particulares (chamado nganga n'kisi) e que corria sempre o risco de ter sua legitimidade questionada por conta do caráter privado de seus ritos. ${ }^{36}$

\footnotetext{
${ }^{33}$ Ibid., Livro Segundo, § 51, p. 206 (os itálicos são da edição consultada).

${ }^{34}$ MACGAFFEY, op. cit., p. 138.

${ }^{35}$ CAVAZZI DE MONTECÚCCOLO, op. cit., Livro Segundo, § 58, p. 209 (os itálicos são da edição consultada).

${ }^{36}$ MACGAFFEY, op. cit., p. 173.
} 
Nessa sentido, também era muito mais próxima daquela das feiticeiras portuguesas no Reino, marcada pela ambigüidade e pelo risco de denúncia a poderes de normatização religiosa que não consideravam sua atuação como legítima, especialmente o Santo Ofício.

Além disso, Cavazzi reitera em várias passagens o fato de que os xinguilas realizavam sacrifícios humanos e antropofagia. É difícil saber em que medida isso poderia corresponder à projeção de um estereótipo hostil, oriundo da demonologia eclesiástica, sobre os sacerdotes imbangalas. Mas um fato deve ser levado em conta: o relato do capuchinho descreve muitos tipos de sacerdotes, e a maior parte deles não é descrito como realizando sacrifícios humanos ou antropofagia. Os xinguilas representam aqui uma exceção significativa: ou de fato eles realizavam práticas concretas que se aproximavam mais dos estereótipos da bruxa homicida e canibal (imaginário a partir do qual o discurso eclesiástico demonizador lia os sacerdotes pagãos), ou então havia algum motivo especial para aproximá-los do estereótipo mais do que a outros sacerdotes, de forma arbitrária. Um dos motivos para a segunda opção poderia ser sua ligação privilegiada com poderes políticos hostis ao catolicismo. Contudo, a hipótese de que suas práticas incluíssem o sacrifício humano e/ou a antropofagia não pode ser descartada; neste caso, é claro que Luzia Pinta negligenciou esses aspectos do ritual dos xinguilas, o que constituiria mais um ponto de afastamento entre as práticas africanas e os calundus coloniais. Evidentemente, os sacrifícios humanos e a antropofagia, além de não terem nenhum paralelo possível com as práticas mágicas européias do catolicismo popular (o que romperia a legitimidade ampliada derivada da dupla interpretabilidade), definitivamente não tinham lugar no contexto social luso-americano.

A isso tudo podemos adicionar um detalhe importante: Luzia Pinta nunca foi uma sacerdotisa xinguila, já que, em primeiro lugar, não tinha nem idade para isso quando deixou Luanda a bordo de um tumbeiro, e em segundo lugar, vivera na cidade cristã de Luanda. É impossível saber se esses procedimentos rituais que ela executava em Sabará, e que guardavam tantas semelhanças com os ritos dos xinguilas em Angola, haviam sido recriados a partir da memória de experiências religiosas que ela tivera em Angola antes de ser traficada, a partir de histórias ouvidas da boca de parentes, ou se foram aprendidos com outros praticantes de magia de origem africana já nas Minas Gerais, como o mencionado preto Miguel. Já identificamos em operação nas Minas uma rede de iniciações mágicas, e nada nos impede de pensar que Luzia Pinta possa ter 
aprendido com esses praticantes afro-americanos os procedimentos de seu ofício. Neste caso, somos levados a conceber na região de Sabará uma comunidade de praticantes de ritos mágico-religiosos de matriz centro-africana.

Isso tudo nos leva a compreender o processo de mediação simbólica de forma mais complexa do que um transplante de ritos centro-africanos para Sabará. Notamos que, para Luzia Pinta, o repertório de práticas dos xinguilas foi antes um código sobre o qual ela (ou quem quer que tenha reproduzido esses elementos na América Portuguesa e os tenha ensinado a ela) realizou uma interpretação e uma seleção, adotando alguns pontos e ignorando outros que não tinham lugar no contexto luso-americano e para as estratégias de inserção na sociedade colonial. Ao fazê-lo, ela promoveu um diálogo entre as práticas rituais de Angola e as da magia européia. Criou uma interpretação específica do catolicismo popular na qual havia espaço para alguns procedimentos selecionados dos xinguilas, ao mesmo tempo em que elaborava uma interpretação própria da religião de seus conterrâneos em Angola, unindo seletivamente práticas de adivinhos de espíritos locais ligados ao poder político e de curandeiros que atendiam clientes particulares, inserindo-as em um contexto social marcado pelas instituições portuguesas e dialogando com uma tradição católica. Por meio deste processo de interpretações recíprocas de duas tradições em diálogo, criou um texto cultural particular, nem bem português, e nem exatamente angolano, mas um texto próprio da zona de mediação intercultural na qual viveu.

\section{Conclusão: diálogo e violência}

Vimos delinear-se um quadro de estratégias de mediação simbólica que propiciaram a Luzia Pinta a possibilidade de um exercício ritual inserido no universo social e cultural da sociedade luso-americana, efetuando recortes de tradições rituais centro-africanas e promovendo um diálogo entre elas e o catolicismo. Como afirmei, não pretendo sugerir que esse percurso de Luzia Pinta seja de alguma forma paradigmático ou mesmo que tenha sido típico na América Portuguesa. Contudo, sua análise nos revela estratégias discursivas de mediação, mecanismos de recorte, seleção e apropriação de repertórios simbólicos operantes na sociedade colonial e que se punham como horizontes possíveis para africanos que, trazidos à América à força e objetos de uma imposição simbólica violenta, podiam elaborar percursos originais e criar seus próprios espaços de inserção diferencial na sociedade colonial, reproduzindo incessantemente a alteridade que o discurso normatizador tentava a todo custo erradicar. 
Essas estratégias e expedientes não impediram Luzia Pinta de sofrer as arbitrariedades típicas do Santo Ofício: tirada à força da vila onde residia e onde tecera sua rede de laços sociais, mantida em cativeiro por mais de dois anos e submetida a tortura, foi ao fim do processo considerada culpada. Saiu em auto de fé em 20 de junho de 1744 e provavelmente foi observada em hábito penitencial por uma multidão nas ruas, como era costume nessas cerimônias em que a Inquisição ostentava seu poder e reafirmava sua autoridade por meio da demonstração pública, ${ }^{37}$ no mecanismo do espetáculo de regeneração dos discursos de dominação. Culpada de leve suspeita na fé, foi degredada por 4 anos para o Algarve, onde teria que recomeçar, refazer seus laços sociais e redefinir sua identidade - mais uma vez. Não dispomos de informações posteriores a essa data, mas nada nos garante que a forma que encontrou para reconstituir sua vida, no degredo ou em outro lugar posteriormente, não tivesse sido a mesma que encontrara nas Minas Gerais: realizar certas cerimônias mágico-religiosas em que adivinhava e curava por virtude da doença de sua terra, os calundus.

Ironicamente, só temos acesso à trajetória de Luzia Pinta precisamente porque sua estratégia encontrou a resistência truculenta de uma outra estratégia discursiva oposta, esta produzida no centro das instituições normatizadoras da sociedade colonial. Provavelmente nunca poderemos saber quantos outros praticantes africanos de ritos mágico-religiosos empregaram com mais sucesso do que Luzia Pinta o mesmo tipo de estratégia de mediação e diálogo entre as tradições africanas e européias. Para nós, resta a constatação estarrecedora de que só ganhamos acesso aos discursos religiosos afro-luso-americanos por meio de sua derrota frente à brutalidade de um outro discurso normatizador que dominava os mecanismos de produção da memória escrita colonial.

Não podemos ignorar esse fato. Uma história das elaborações simbólicas dos africanos passa também, por mais incômodo que possa parecer, por uma história das tentativas reiteradas de desmontá-las por parte dos discursos coloniais, na economia da aversão e da atenuação das tensões da ordem. As astúcias das estratégias de mediação empregadas por Luzia Pinta e pelos africanos estavam sempre sujeitas ao risco da resistência de um outro discurso que tinha

\footnotetext{
${ }^{37}$ Para uma análise do papel sociológico e da simbologia dos autos de fé em Portugal, vejase SARAIVA, António José. Inquisição e cristãos-novos. Lisboa: Editorial Estampa, 1985.
} 
a seu favor a violência institucionalizada, seja a dos senhores, seja a de órgãos como os tribunais do Santo Ofício. As práticas e discursos da normatização e da subjugação punham-se como presenças constantes, limites com os quais era forçoso que os africanos soubessem negociar, em uma espécie de liberdade condicionada cujo exercício se limitava a certos espaços que tinham de ser criados e reivindicados em uma negociação tensa - e sempre arriscada, como nos mostra a história de Luzia Pinta - com esses poderes. 